\title{
The Typology of the Berlin Block: History, Continuity and Spatial Performance
}

\author{
By Katharina Borsi ${ }^{*}$ \\ Nicole Porter ${ }^{\dagger}$ \\ Megan Nottingham ${ }^{\ddagger}$
}

The Berlin block of the nineteenth century is currently undergoing a renaissance. In a modified form the perimeter block appears in a number of current master plans, such as Bercy, Paris, Barcelona as well as in Berlin. Since the International Building Exhibition of 1984/87 (IBA), Berlin's urban strategy has embraced the formal qualities of the block. Its vibrant street life, dynamic mix of uses and functions are as well as its spatiality of defining urban space are the qualities sought in the regeneration of the existing fabric as well as in new developments. This paper draws a comparison between Rob Krier's winning competition project of 1979 and the nineteenth century Berlin block; it argues that the debate surrounding the formal premise of the IBA, with its explicit focus on history as a mode of analysis, classification and re-interpretation, renders a static taxonomy of form and thereby underemphasizes architecture's contribution to the city in its formal and organizational capacity.

\section{Introduction: The International Building Exhibition 1984/87}

The IBA is understood as exemplifying a sea change in the approach towards development and regeneration. ${ }^{1}$ Sensitive restoration of the existing urban fabric instead of large scale demolition; the integration of participatory planning processes instead of large scale displacement of the urban population; working with and enhancing the existing urban qualities instead of a tabula rasa approach; and urban regeneration by sensitive infill projects referencing and restoring the historical plan continue to be seen as exemplary approaches for current urban regeneration. Formally, the proponents of the IBA sought a contemporary interpretation of the qualities of the traditional European city, exemplified by the Berlin block and its urban morphology.

In the 1970s, a general disenchantment with modern architecture and planning was as prevalent in Berlin as it was elsewhere. The International Building Exhibition 1984/87 explicitly articulated the departure from modernism. Critics identified the absence of historical continuity in

\footnotetext{
* Assistant Professor, University of Nottingham, United Kingdom.

${ }^{\dagger}$ Assistant Professor, University of Nottingham, United Kingdom.

${ }^{\ddagger}$ PhD Researcher, University of Nottingham, United Kingdom.

1. Harald Bodenschatz, Vittorio Magnago Lampugnani and Wolfgang Sonne (Eds.) "25 Jahre Internationale Bauaustellung Berlin 1987. Ein Wendepunkt des europaischen Städtebaus," in Bücher zur Stadtbaukunst Band 3 (Sulgen: Deutsches Institut fur Stadtbaukunst: Niggli, 2012).
} 
architectural and urban form at the time. ${ }^{2}$ Josef Paul Kleihues critiqued the separation of tenants from one another and from the urban space below, and argued that the anonymity that came with life in modernist slabs and tower blocks was paralleled with the fragmentation of the city fabric. ${ }^{3}$ In addition, a housing crisis and social unrest sparked the need for the search for new housing forms and policies. ${ }^{4}$ Thus, the "widely criticized, inhospitable modern city' searched-for a solution for housing developments but also to restore the city's 'lost identity' and image as a 'cultural metropolis' on the international scene. ${ }^{5}$

The IBA had two thematic streams: 'careful renewal' and 'critical reconstruction'. The first was deployed in the IBA ALTBAU, to 'work with and not against the [existing] urban form'. ${ }^{6}$ IBA Neubau, under the leadership of Josef Paul Kleihues, adopted a context sensitive approach to the construction of new projects, predominantly housing developments. The projects were small, rarely larger than 150 dwellings in each scheme, and developed through a design approach resonating formal aspects of the nineteenth century urban structure, entitled 'Critical Reconstruction'.

Alan Colquhoun (1989) explained the formal objectives of the IBA as follows:

- It sees the city with its perimeter blocks and streets, as solid, anonymous fabric which should contain a variety of functions, including housing and commerce

- The new isolated buildings, whether old or modern, would gain symbolic importance by contrast with this continuous fabric

- It reinstates the street and the public square as the places of unprogrammed public enjoyment and congregation

2. Emily Pugh, "Beyond the Berlin Myth: The Local, the Global and the IBA 87," in Berlin Divided City, 1945-1989, 156-167, ed. P. Broadbent and S. Hake (USA: 2010).

3. Josef Paul Kleihues, and Wolf Jobst Siedler (1977), "IBA's Models for a City: Housing and the Image of Cold-War Berlin," in Wallis Miller, The Journal of Architectural Education 46, no. 4 (1993): 205.

4. Harald Bodenschatz, Berlin Urban Design, a Brief History, (Berlin: DOM Publishers, 2010).

5. Emily Pugh, "Beyond the Berlin Myth: The Local, the Global and the IBA 87," in Berlin Divided City, 1945-1989, ed. P. Broadbent and S. Hake (USA: 2010), 156-167; West Berlin Senate, LArch; B Rep. 150/416, Mitteilung Nr 105.

6. Peter Testa, "Unity of the Discontinuous: Alvaro Siza's Berlin Works," Assemblage, no. 2 (1987): 48.

7. See: Harald Bodenschatz, Berlin Urban Design, A Brief History(Berlin: DOM Publishers, 2010); Emily Pugh, The Berlin Wall and the Urban Space and Experience of East and West Berlin, 1961-1989 (Michigan, 2008). An international array of architects, such as Peter Eisenman, Herman Hertzberger, Arata Isosaki, Rob Krier, Aldo Rossi, Alvaro Siza, Robert Stern and James Stirling received commissions to built within the framework of the IBA and contributed with a diverse array of styles their version of 'critically reconstructing' the historical city fabric. The selected regeneration areas were located in the most deprived parts of the city; The IBA Neubau projects were undertaken in Tegel, Prager Platz, Southern Tiergarten, Southern Friedrichstadt, whereas the IBA Altbau focused on the regeneration of one part of the large district of Kreuzberg -- SO36. 
- It reinforces the pedestrian scale and rejects the dominance of fast, motorized circulation

- It sees the public space of the city as more analogous to so many external rooms and corridors, with definite boundaries, than to limitless voids within which buildings, circulation routes, etc., occur

- Finally it conceives of the city as historically as well as spatially continuous - capable of being read as a palimpsest. ${ }^{8}$

Rob Krier similarly underwrites this restoration of the urban structure. He argues that the 'loss of urban space' in modern urbanism led to what he perceived as the 'crisis of the city'. 9 The segregation of the city into functional zones as promoted by the Charter of Athens and the profit hungry lobby condoning this development are his main perpetrators. ${ }^{10}$ Modernisms fixation onto individual buildings as isolated figures abandoned the public space of the city and with it civic urban life. Accordingly, postmodern urbanism ought to return the boundedness of the city it displayed historically.

The instrument for postmodern urbanism is urban repair. Krier's urban vision proposes that the city is a sequence of buildings defining bounded urban spaces - particularly clearly articulated squares and streets. In his seminal Stadtraum in Theorie und Praxis (Urban Space in Theory and Practice) of 1975 Krier assembled a morphological taxonomy of street and square types derived from historical precedents.

\section{Ritterstrasse - Reinstating the Block}

Krier's urban plan for the development of Ritterstrasse precisely aims to restore the structure of the nineteenth century urban plan by inserting perimeter blocks lining the street, but further subdivided with four internal courtyards and pedestrian streets crossing it. Krier drew upon another six architectural practices to develop individual buildings to ensure variety in the block's external expressions. The project contained 35 different buildings with 315 dwellings, built in 1982/83 and 1986-1988. Two existing buildings were integrated in the outline of the perimeter blocks.

The overall composition both references and adapts the nineteenth century plan. The perimeter blocks lining the external streets follow the height of the nineteenth century block and thereby complete the defined urban space of the street (see Figure 1). Whereas the nineteenth century block folds inwards to reveal one or two sequential courtyards, in Krier's project the external perimeter encloses a cruciform of two secondary streets; distributing four courtyards lined with four storey buildings (see Figure 2). His morphology

8. Alan Colquhoun, Modernity and the Classical Tradition, Architectural Essays 19801987 (London: The MIT Press, 1989).

9. Rob Krier, Urban Space (New York: Rizzoli International, 1979), 49.

10. __. Stadtraum in Theorie und Praxis (Stuttgart: Karl Kramer Verlag, 1975), 67. 
Vol. 2, No. $1 \quad$ Borsi: The Typology of the Berlin Block: History, Continuity...

carves out a clearly defined hierarchy of spaces: the street of the urban grid, the perimeter blocks, the internal streets and the courtyards clearly demarcate public, semi-public and private spaces (see Figure 3).

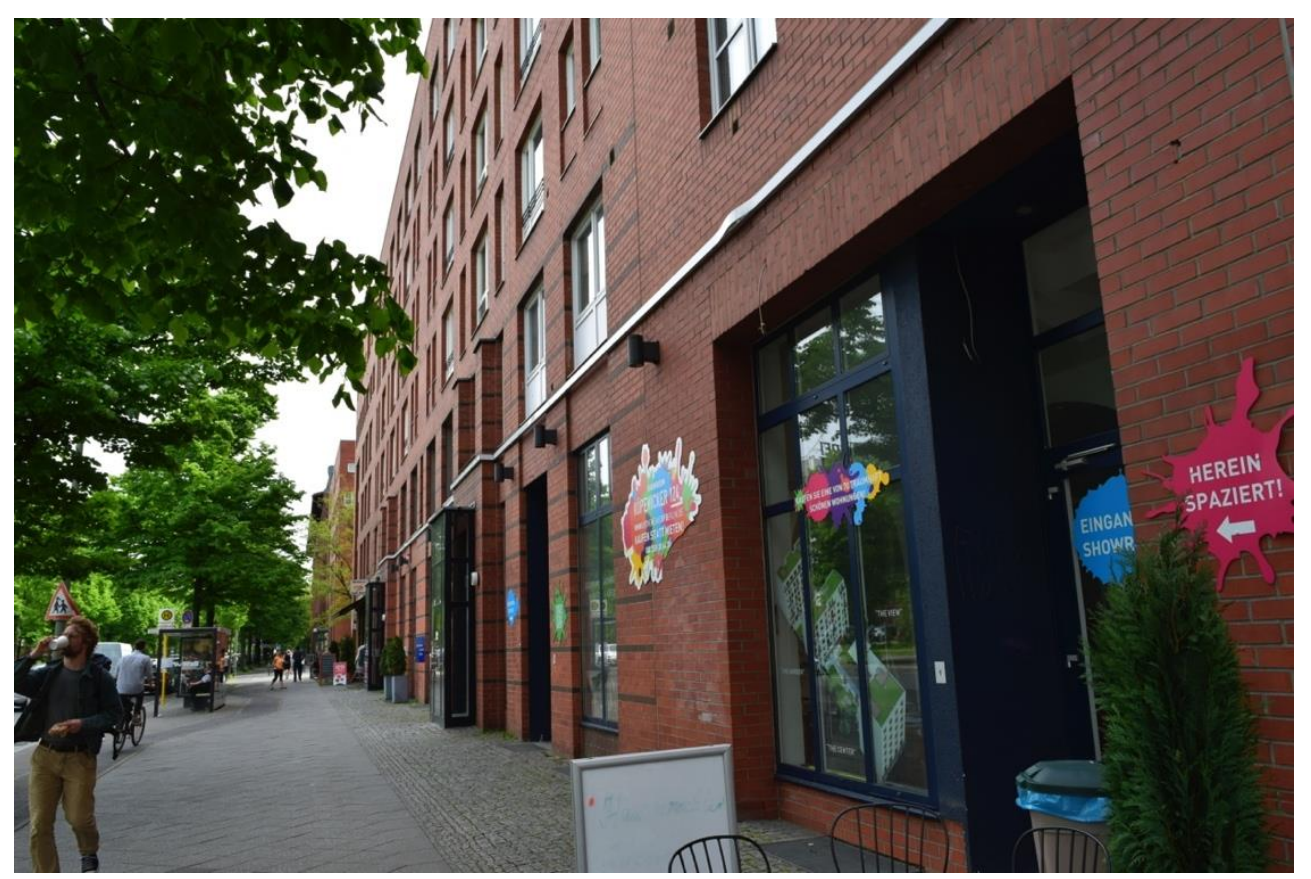

Figure 1. Elevation along Oranienstrasse

Source: Photograph by Megan Nottingham, 2015.

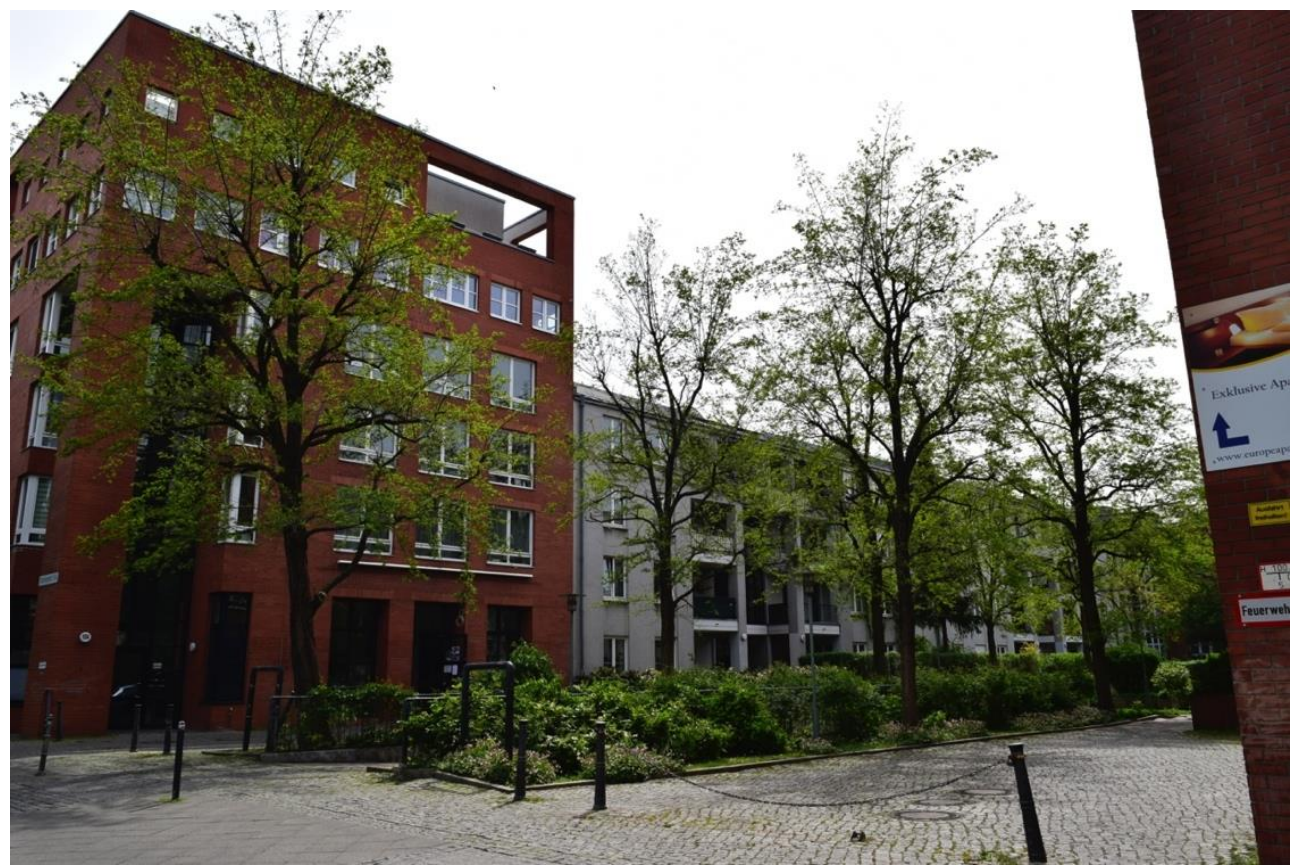

Figure 2. Entrance into the Internal Street from Oranienstrasse

Source: Photograph by Megan Nottingham, 2015. 


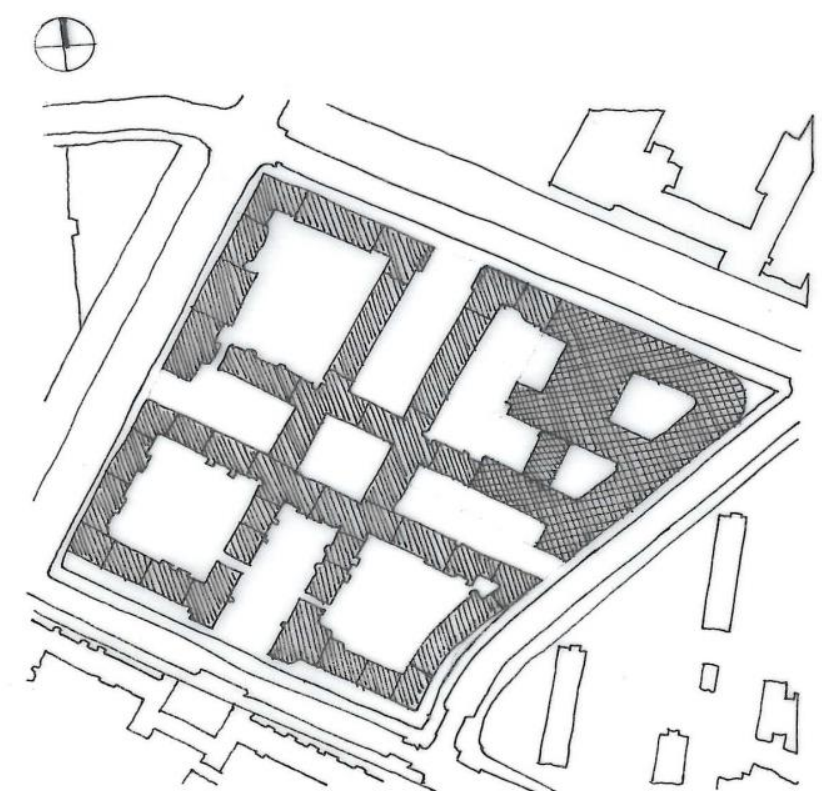

Figure 3. Ritterstrasse IBA Block Plan

Source: Redrawn by Megan Nottingham from: IBA Prospectus: IBA'87 Sudliche Friedrichstadt und Tegel, Baukultur und junge Stadtgeschichte im Focus, Senatsverwaltung fur Stadtenwicklung und Umwelt, Berlin, 2008.

The plan connects four continuous blocks with their private courts to a central square. In this way, each apartment faces two orientations - a street and a courtyard, allowing tenants to relate to the street life as well as to the quiet block interior (see Figure 4). Similarly to the nineteenth century structure of the area, the perimeter block is composed of individual, adjoining buildings, executed by a variety of different architects, and accordingly varied in their facades.

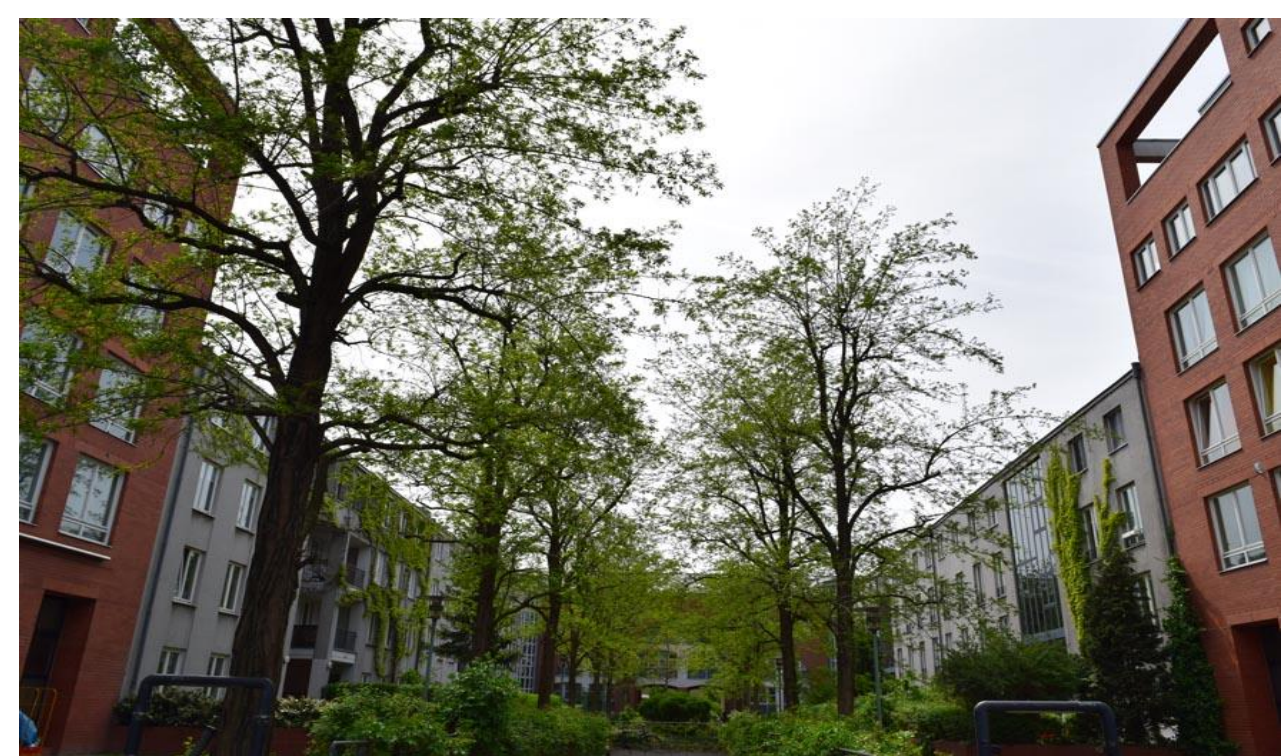

Figure 4. Views into Residential Street

Source: Photograph by Megan Nottingham, 2015. 
Krier said about his Ritterstrasse development in Berlin:

I have proposed that the edge of the block be subdivided into manageable plots for a number of reasons, most importantly: To put a halt to fast-track production of housing by a single architect and so give work to other architects. To re-establish small groups which will again allow people to get to know their neighbours. To create a small-scale architecture that is easy to recognise and orient oneself by. To recognise that housing can only rise above other functions of the city if it once again takes on the variety that in the past characterised, enlivened and enriched the streetscape. ${ }^{11}$

Figure 5. Courtyard and Street Connections

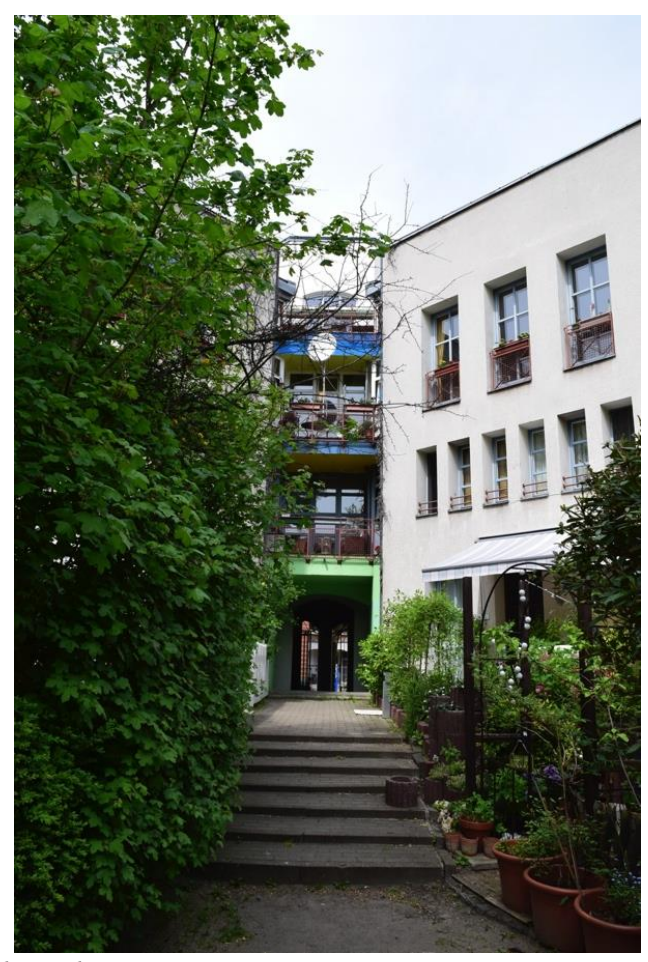

Source: Photograph by Megan Nottingham, 2015.

A set of gateway buildings, arranged in pairs, create a link between the courtyards and the street (see Figure 5) On the south side of Ritterstrasse, the four story building by Krier signals access to the depth of the block by stretching the gateway into a long, low arch, referencing the famous Karl Marx Hof in Vienna (see Figure 6). Two sidewings provide an offset asymmetry to the axial opening by variations in the composition of the loggias and balconies. A sculpted figure 'supervises' the entrance.

11. Rob Krier, Architecture and Urban Design (London: Academy Editions, 1993), 41 


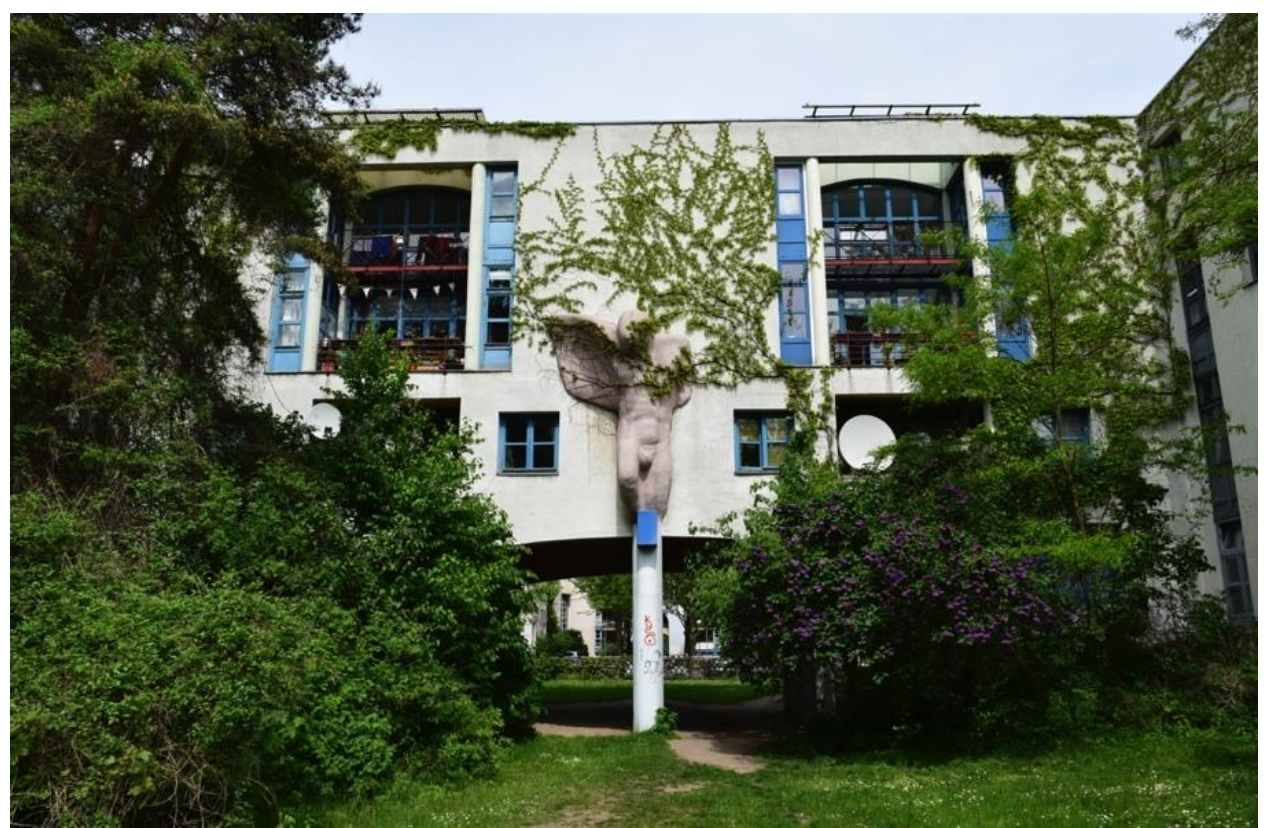

Figure 6. Krier's Entry Arch

Source: Photograph by Megan Nottingham, 2015.

At the crossroads of the internal streets sits the centrepiece of the development, Schinkelplatz (see Figure 7). Four-storey buildings define the small, seemingly Italianate, urban square, landscaped with hard surfaces and trees. Since the site had contained the Feilner House, an apartment building by Karl Friedrich Schinkel, Krier reconstructed and integrated its façade in his development (see Figure 8).

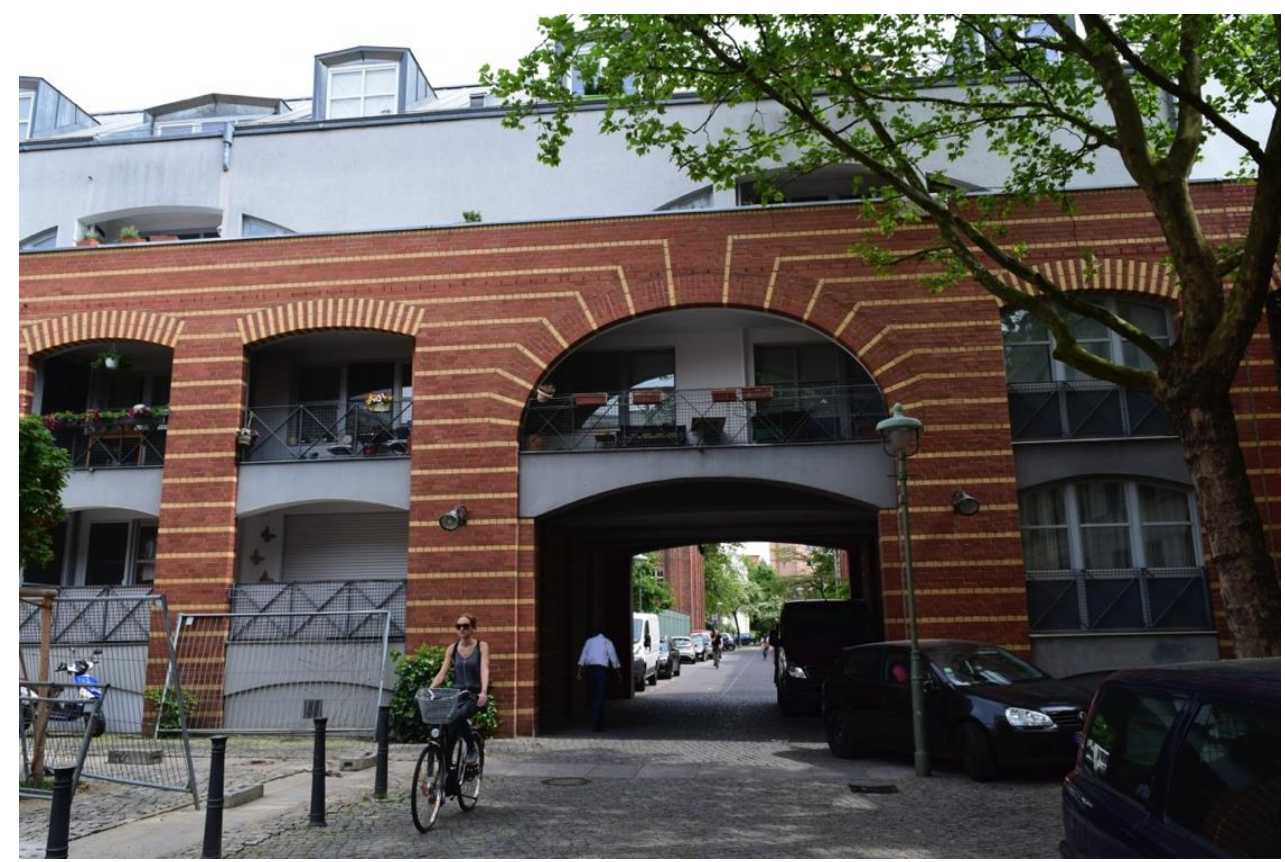

Figure 7. Schinkelplatz

Source: Photograph by Megan Nottingham, 2015. 


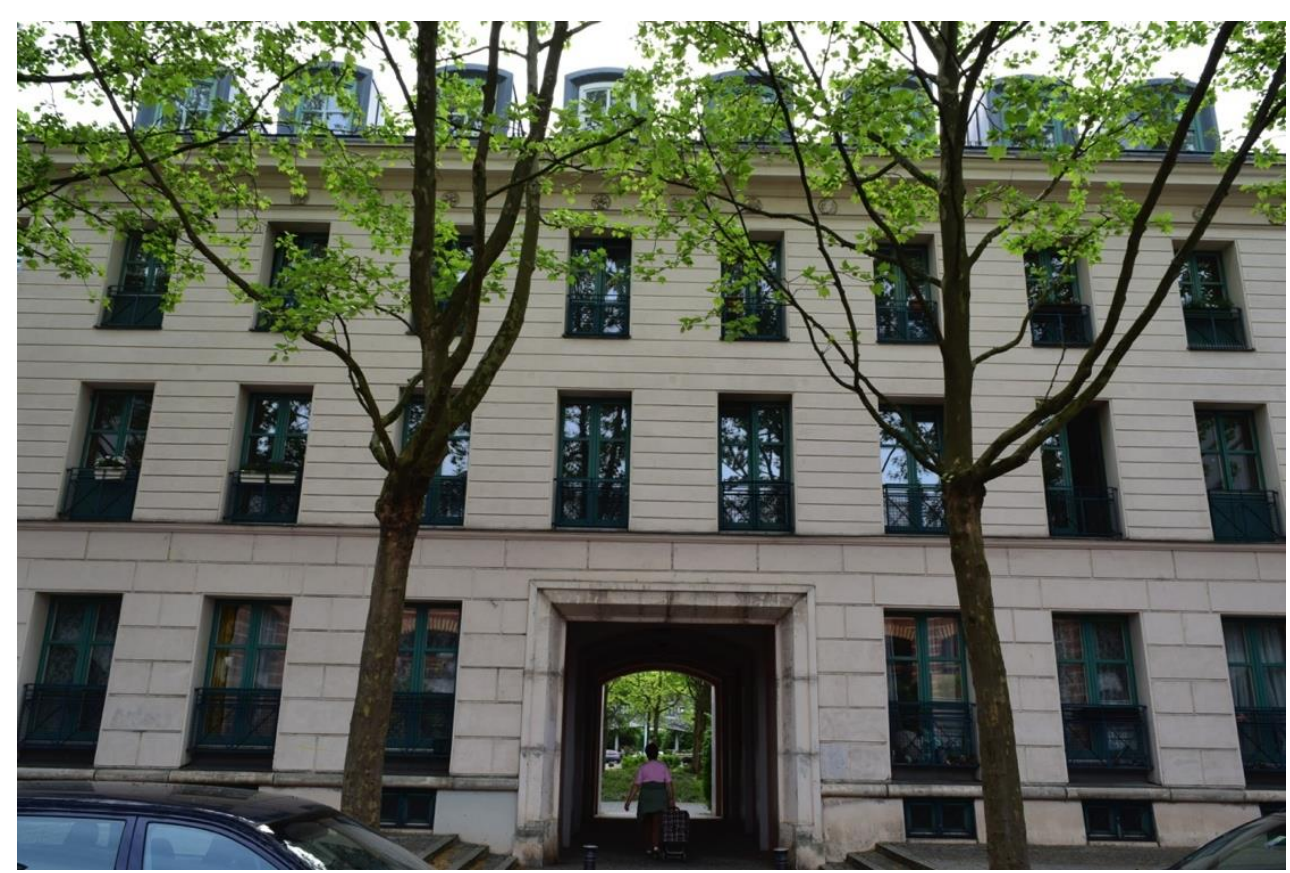

Figure 8. The Reconstructed Feilner House

Source: Photograph by Megan Nottingham, 2015.

In plan (see Figure 9), special attention was given to the design of shared entries and stairways in recognition of the influence they have on the way residents identify with each other and their buildings. Balconies within the block interiors provide a more intimate connection with the void of the courtyard, which is given a different character in each court. Landscaping with trees, pergolas and trellises and various surface treatments offer spaces for relaxation and play (see Figures 10 and 11).

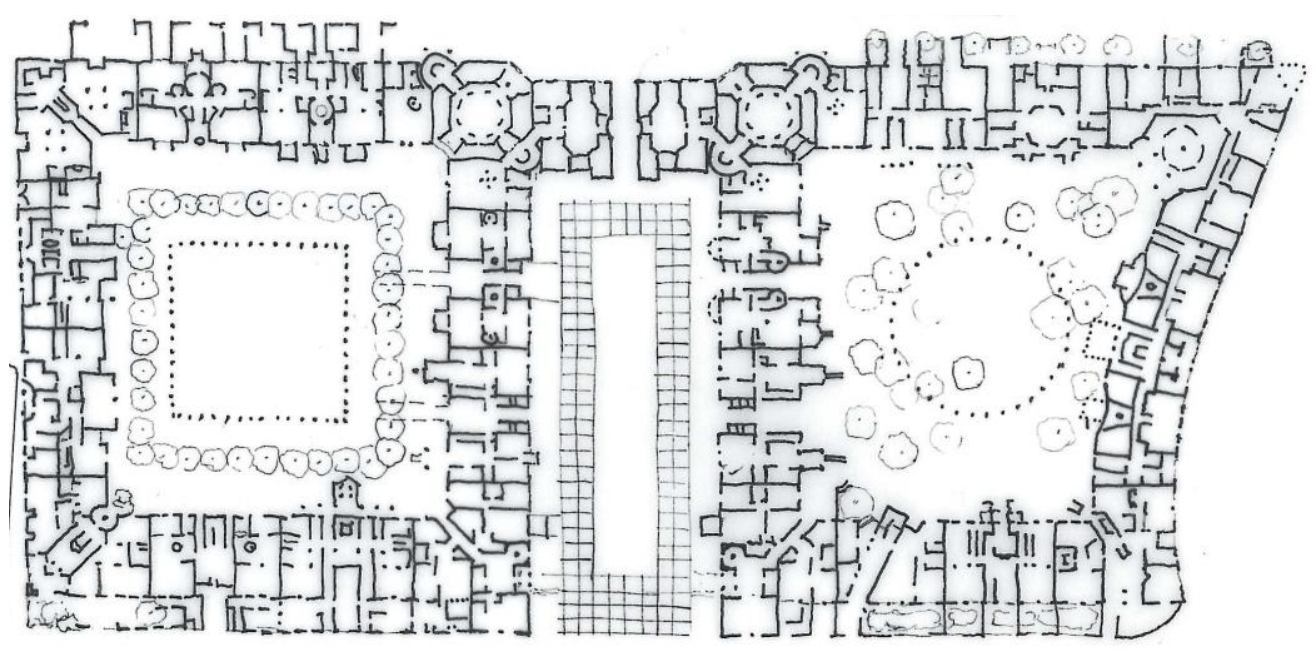

Figure 9. Plan of Block 31

Source: Redrawn by Megan Nottingham, 2015, from Architectural Review, Ritterstrasse Nord: Friedrichstadt, 1987(9): 5. 


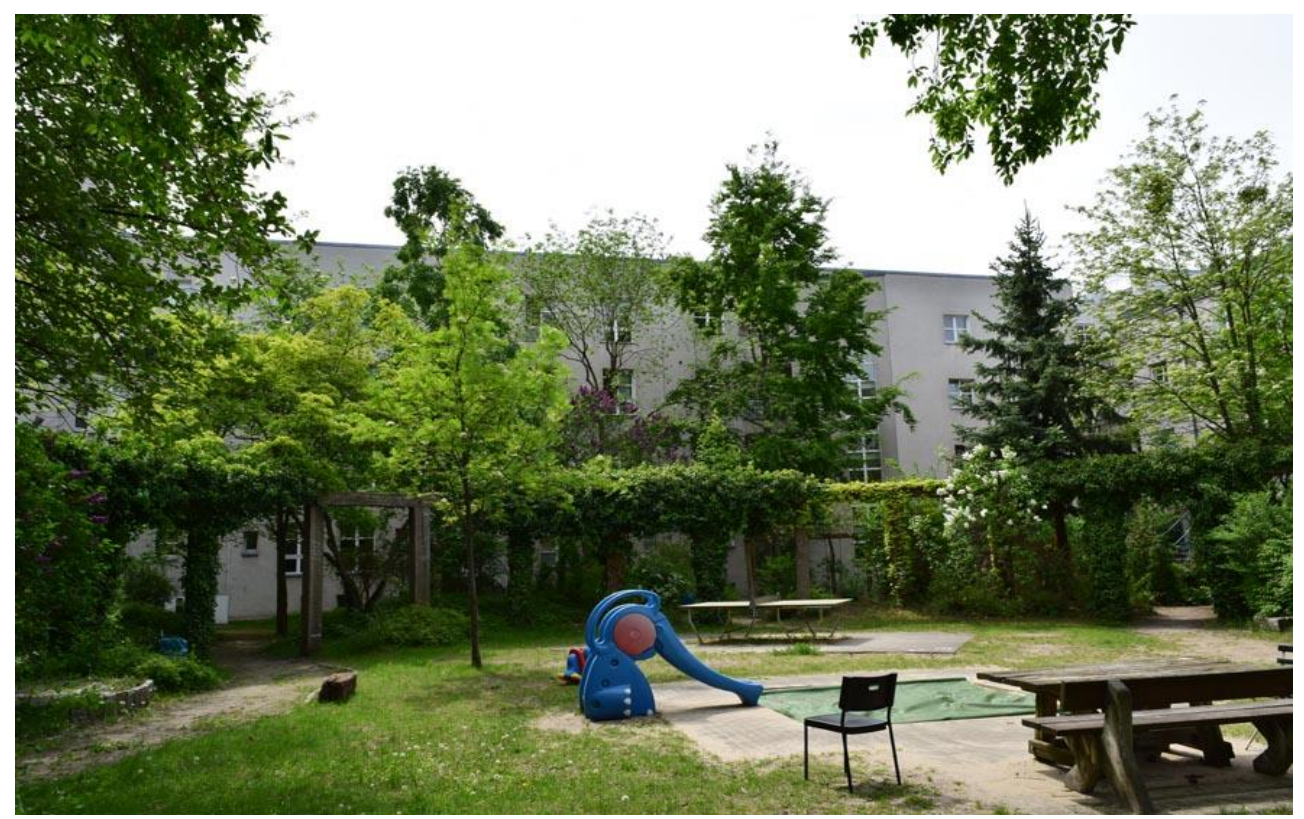

Figure 10. View into Courtyard

Source: Photograph by Megan Nottingham, 2015.

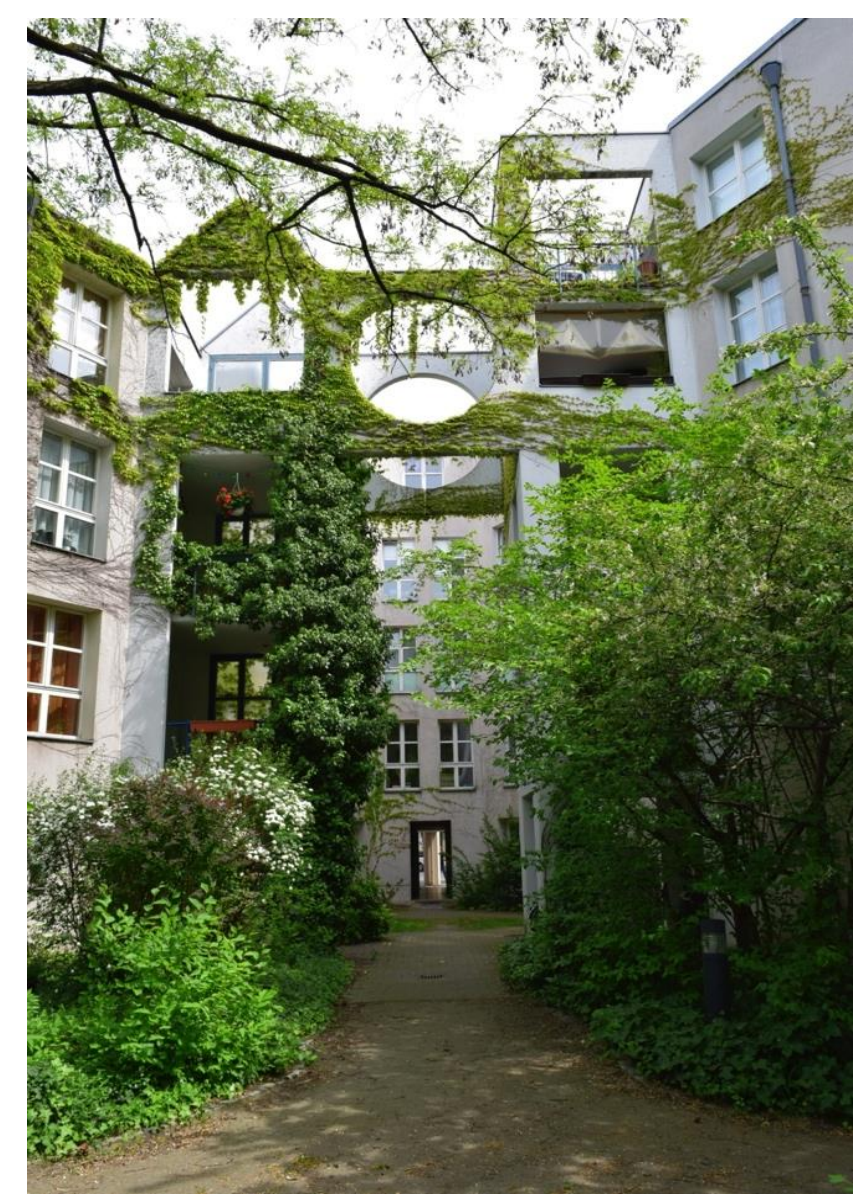

Figure 11. View into Courtyard

Source: Photograph by Megan Nottingham, 2015. 
In Krier's plans surrounding Schinkelplatz (see Figure 9, the floorplans in the middle of the upper perimeter block), the individual character of each apartment was differentiated through the shape of the central living room, which was projected as shaped rounds, octagons or squares. ${ }^{12}$ Krier explains his intentions as follows:

in the plan, the layout of the rooms was decided to be started from the living room - which takes on the shape of a flattened octagon and proceeding via the hexagonal entrance hall to the seven sided staircase hall. This is not a case of geometrical fetishism, but simply a logical development of the concept of a principle room in which the secondary ones are connected. The form of the living room grows out of the need to enlarge it in the middle, since it is the family's meeting point, the 'heart of the home' (L.B. Alberti)...13

Kenneth Frampton argued that Krier's plans were determined by shapes and sequences according to nineteenth -century bourgeois standards of deportment, but realised through the minimum standards of social housing, which inevitable led to an unduly restricted aggregation of spaces. ${ }^{14}$ Similarly, also Deborah Berke describes Krier's central spaces as resulting in awkward geometries in the peripheral rooms, and as giving no indication of how the central room could actually be furnished or used effectively, given hat each room has at least four doors, each in a different wall. ${ }^{15}$ She argues that Krier's rigid geometry precluded simultaneous circulation and static room use.

Krier's ambition was to redeploy the components that made the traditional city memorable and convivial. Krier's deployment of forms served to establish a formal dialectic between building and space, architecture and the city, the public and the private. His vision of urban living sees a clear correlation between the reinstatement of architectural and urban form with the appreciation by its users, even when at times this takes on a somewhat condescending tone:

the intimate and introverted quality of the square and the adjacent block structure will undoubtedly facilitate the initial process of adaptation by its first inhabitants. Moreover, many Turks live in Kreuzberg and I am convinced that this ethnic group still remembers, having learned their lesson in their homeland, how to feel at home in a square and a street. It

12. Kenneth Frampton, Modern Architecture a Critical History (London: Thames and Hudson, 1987), 5.

13. Rob Krier, "Rob Krier Urban Projects 1968-1982," in D. Berke, K. Frampton, S. Kolbowski and R. Krier (New York: Institute for Architecture and Urban Studies: Rizzoli International Publications, 1982a), 5.

14. Kenneth Frampton, "Rob Krier Urban Projects 1968-1982," in D. Berke, K. Frampton, S. Kolbowski and R. Krier (New York: Institute for Architecture and Urban Studies: Rizzoli International Publications, 1982), 2-9.

15. Deborah Berke, “Rob Krier Urban Projects 1968-1982,” in D. Berke, K., Frampton, S., Kolbowski and R., Krier (New York: Institute for Architecture and Urban Studies: Rizzoli International Publications, 1982), 10-13. 
would be nice of the means could be found to decorate the square with stelae and figures, with images that can be read and would help people to understand themselves. I have suggested that the square should be named after Karl Friedrich Schinkel. ${ }^{16}$

Ritterstrasse spatial and formal articulation exemplifies many of the formal objectives of the IBA as explained by Colquhoun above. It can be read as an urban component configures by perimeter blocks and streets; however, some of its postmodern facade articulation might not be as 'anonymous' as Colquhoun would have wished; it seeks to reinstate the street and the public square as the places of unprogrammed public enjoyment and congregation through the articulation of voids and differentiated landscaping; its bounded courtyards can be read as seeing 'the public space of the city as more analogous to so many external rooms and corridors, with definite boundaries, than to limitless voids within which buildings, circulation routes, etc., occur', and its siting in the urban context 'conceives of the city as historically as well as spatially continuous - capable of being read as a palimpsest. ${ }^{17}$

Krier's Ritterstrasse has been met with both accolades and severe criticism. It is considered as a key example of contextual urban development and inner city housing. In particular, his treatment of the publicly accessible outdoor spaces is recognized as outstanding. ${ }^{18}$ On the other side, a statement by Kleihues exemplifies how Krier's historicism came under scrutiny:

I would consider Rob Krier's work to be especially typical of postmodernistic thinking in architecture; [Krier's] type of historicism is really very nostalgic and conservative; it is a trend that is heavily impregnated with resignation, and manifests little hope of faith in the future; it is problematical because as regards social considerations it calls for an orientation on the past that is not viable. ${ }^{19}$

Particularly his use of historical quotations was attacked. The architectural critic Dieter Hoffman Axthelm, one of the intellectual figureheads of the IBA, critiqued the inauthenticity in Krier's reconstruction of the Feilner House on Schinkelplatz. He saw Krier's insertion of historic façade components, taken from elsewhere, as exemplifying an urban image without history, given that this formal move can be multiplied randomly given that it is removed from historical time and place. $^{20}$

Krier's Ritterstrasse provides until the present day a high quality urban

16. Krier, "Rob Krier Urban Projects 1968-1982," 5.

17. Colquhoun, Modernity and the Classical Tradition, Architectural Essays 1980-1987, 232

18. Senatsverwaltung für Stadtentwicklung und Umwelt, IBA, '87 - Sudliche Friedrichstadt und Tegel. Baukultur und junge Stadtgeschichte in Fokus (Berlin: 2014).

19. Josef Kleihues and Heinrich Klotz (Ed.) "International Building Exhibition Berlin 1987," in Examples of New Architecture (London: Academy Editions, 1986), 11.

20. Dieter Hoffmann-Axthelm, Wie kommt die Geschichte ins Entwerfen? Aufsätze zu Architektur und Stadt (Berlin: Springer Vieweg, 1987). 
residential environment. Its density, variety of dwelling layouts and the high quality of well-defined outdoor spaces provide a rich, varied environment for its inhabitants and the urban district.

The following comparison with the nineteenth century berlin block does not serve to critique Ritterstrasse's architectural and urban contribution. Instead it provides an alternative reading of historical continuity and an investigation of the use of historic precedent. We argue that the 'images that can be read and would help people to understand themselves' as Krier describes the role of his historical quotations, as well as the inauthenticity perceived by HoffmannAxthelm or the resignation Kleihues reads into Krier's historicism render the past as a static set of images. Instead, the description of the nineteenth century block serves to demonstrate the possibility of history not so much as a formal quotation, or repetition of form, but instead as a spatial performance inherent in its organizational specificity.

\section{The Performance of the Nineteenth Century Block}

Borsi (2009) has previously noted that the extension plan of 1862 by James Hobrecht and the concurrent drawings of the block as a fabric of interlinked spaces, similar to Choay's descriptions of Cerdá's conception of the city as an interconnected 'urban framework' that links the city all the way from its overall surface to the urban block, down to the single room. ${ }^{21}$ Hobrecht's extension plan, conceived the city as a unified system of interrelated spaces, whereby a regularly distributed system of spaces of movement - for air, drainage and people-organized the regular distribution of spatially and programmatically undifferentiated urban fabric. In conjunction, the organization of its typological component, the Berlin block, provides a similarly undifferentiated system for building the entire city. The book chapter described how Gustav Assmann's Plans for Urban Dwellings, also from 1862, exemplified the spatial performance of the block as a flexible, adaptable series of spaces, into which the possibility of adaptation is inscribed. ${ }^{22}$ Assmann explicitly argued for the creation of generous and generic spaces that can be linked or subtracted from each other, since the main function of these buildings was to provide for the possibility of different uses and a fluctuating population.

The rendered ground floor drawing around Oranienstrasse shows a relatively porous spatial pattern at ground level (See Figure 12). This permeability across the built fabric complements Assmann's description of the block's interior as a variable number of linked spaces, underlining the flexible

21. Katharina Borsi, "Strategies of the Berlin Block," in Intimate Metropolis, 132-152. Edited by V. Di Palma, D. Periton and M. Lathouri (Abingdon, Oxon: Routledge, 2009).

22. Gustav Assmann, Grundrisse für städtische Wohngebäude. Mit Rücksicht auf die für Berlin geltende Bauordnung (Berlin: 1862). 
nature of boundaries from the space of the street all the way to the single room. The drawing exemplifies the performance of the single buildings as part of a system in which the block's repetition generates the spatiality of the whole city. As such, in the 1870 s, the plans of the block and the urban plan provided the grounds for understanding the city as an infrastructural system that collects and distributes an as yet undifferentiated population and a multiplicity of uses throughout its territory.

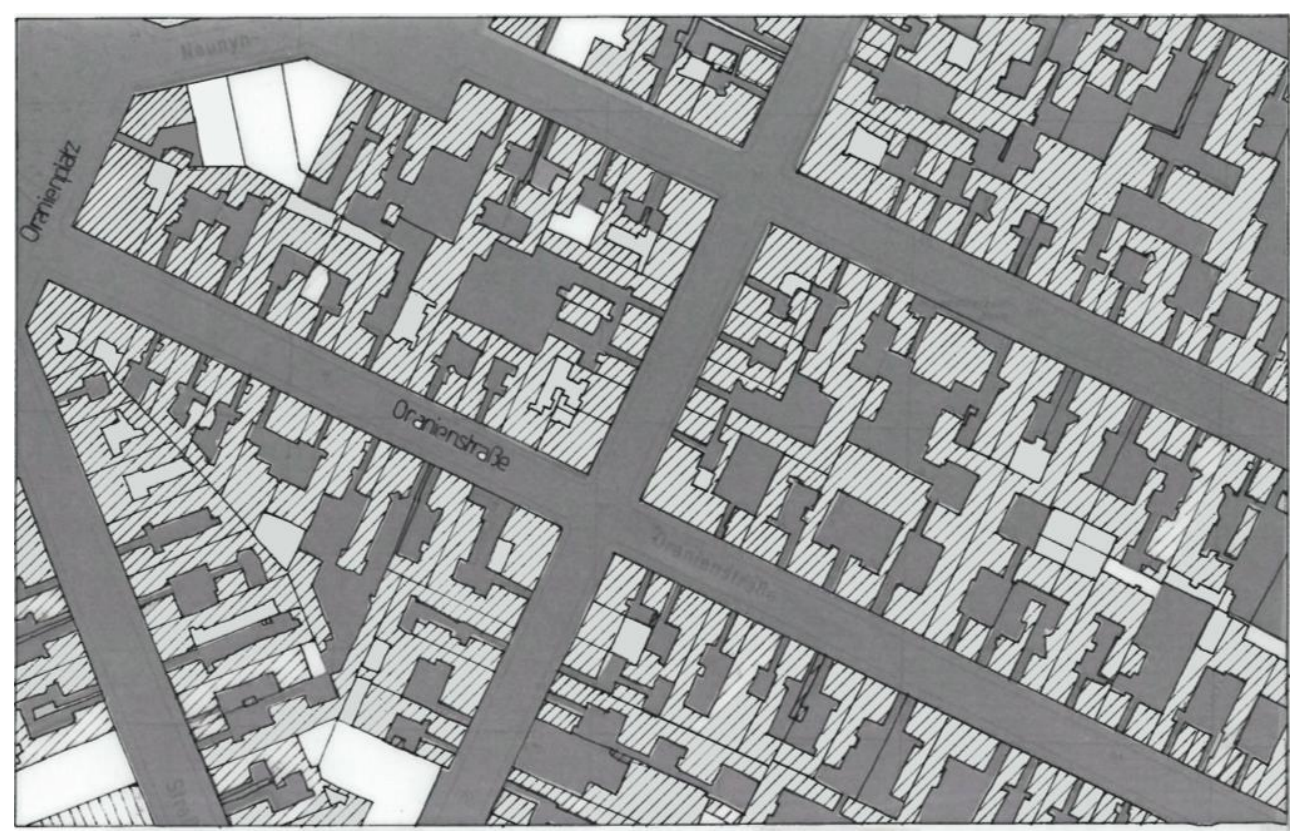

Figure 12. Porosity at the Ground Level

Source: Redrawn by Megan Nottingham, 2014, from: Jonas Geist and Klaus Kürvers, Das Berlin Miethaus, Munich Prestel Verlag, 1980-89 (2): 279. (Landesarchiv Berlin F Rep. 270, Nr A 2999).

It is this flexibility, adaptability and close interconnectivity between the internal spaces of the block, the courtyards and the space of the street that continues to be legible in the urban fabric of Oranienstrasse today.

The fabric of the urban block between Skalitzer Strasse, Erkelenz-damm and Oranienstrasse was predominantly developed between the 1850s and the 1880 s, based originally on a plan by Peter Joseph Lenne in 1840, and with the implementation of the Hobrecht plan in 1875, further densified.

From the outset, Kreuzberg, with Oranienstrasse as one of its central streets, was intensely occupied with light industries, whereby production, manufacture, trade and living coexisted in a particular synergy. While many of its individual blocks in the late nineteenth century were built with steel structures as factories surrounding the second and third courtyards, common practice at the time was the coexistence of home and light industries in the spaces of the block. The block's generous spaces, designed as described above for flexibility and adaption could be subdivided and newly arrayed, offering a 
system of change of spatial requirement according to need. ${ }^{23}$ The spatial structure enabled this particular quality of proximity of working and living, the possibility of small and medium sized trade and industries to coexist, network and establish synergies. Scaling up or down spatially, establishing networks of collaboration across scales, dispersing and rearranging across the spaces of blocks or the quarter allowed economies of agglomeration to persist equally in the nineteenth century form of production and trade or current forms of working in the knowledge industries. This 'Kreuzberg Mix' was rediscovered as being of value through the IBA Altbau, which sought to enhance and strengthen the social mix of its inhabitants and the broad range of functions.

Stefan Krätke, in his study on the Creative Capital of Cities notes how the built fabric of Kreuzberg supports the concentration of cultural economies, particularly the music industry. ${ }^{24} \mathrm{He}$ describes Kreuzberg as one of Berlin's districts with extreme high concentration of firms and micro firms. The district functions as a spatially overlapping local agglomeration of firms and actors from different subsectors of the cultural and creative industries, with shared common locational preferences. He argues that thy share a high regards for a local environment that offers a 'creativity-boosting atmosphere' in addition to formal inter-firm ties and cooperative relations and the spatial performance of the 'Berlin-mix', which allows an intermingling of housing, small businesses and productive activities. ${ }^{25}$

The spatial and formal qualities of the Berlin block form part of this programmatic intensity through its density, possibility of flexible inhabitation and proximity of the spaces in the depth of the block to the space of the street

Today, Oranienstrasse at street level serves a vibrant retail and leisure industry, drawing the life of the street into the courtyards who vary in occupation from green residential space and playgrounds, to service yards, to a combination of cultural, industrial and production spaces (see Figures 13-15). While the front building of the block contain much housing, they also house offices or service industries. While particularly the purposefully built factories allow a broad range of creative and other industries, the fundamental possibility of a mix of functions is prevalent everywhere, made possibly by the generosity and undifferentiation of the block (see Figure 16).

23. Peter Hoffmann, "Report from West Berlin,"Architectural Record 173, no. 2 (1985): 67.

24. Stefan Krätke, The Interactive Knowledge Creation and the Urbanization Economies of Innovation (Malden MA: Willey-Blackwell, 2011).

25. see also Senatsverwaltung für Wirtschaft, Technologie und Forschung, Räume der Kreativwirtschaft (Berlin 2008). 


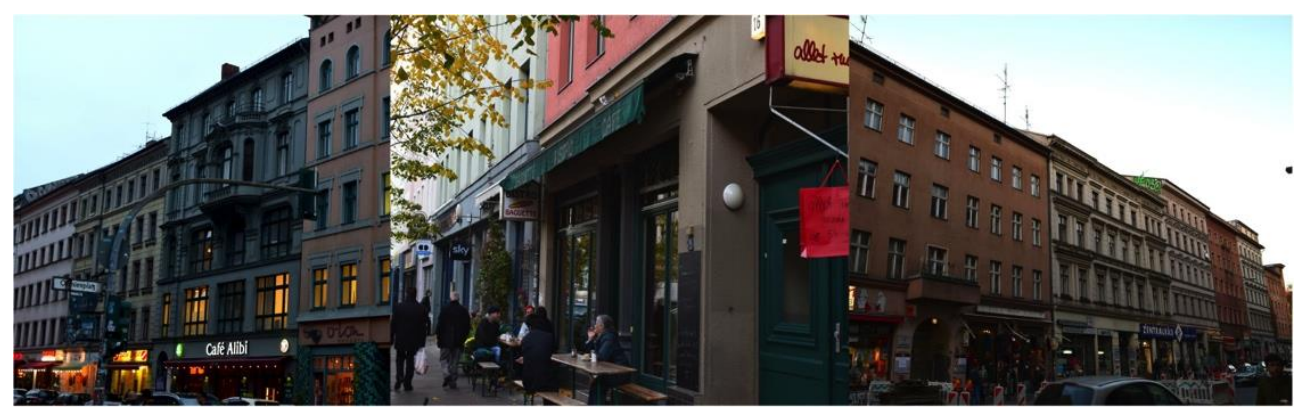

Figure 13. Oranienstrasse

Source: Photographs by Megan Nottingham, 2014.

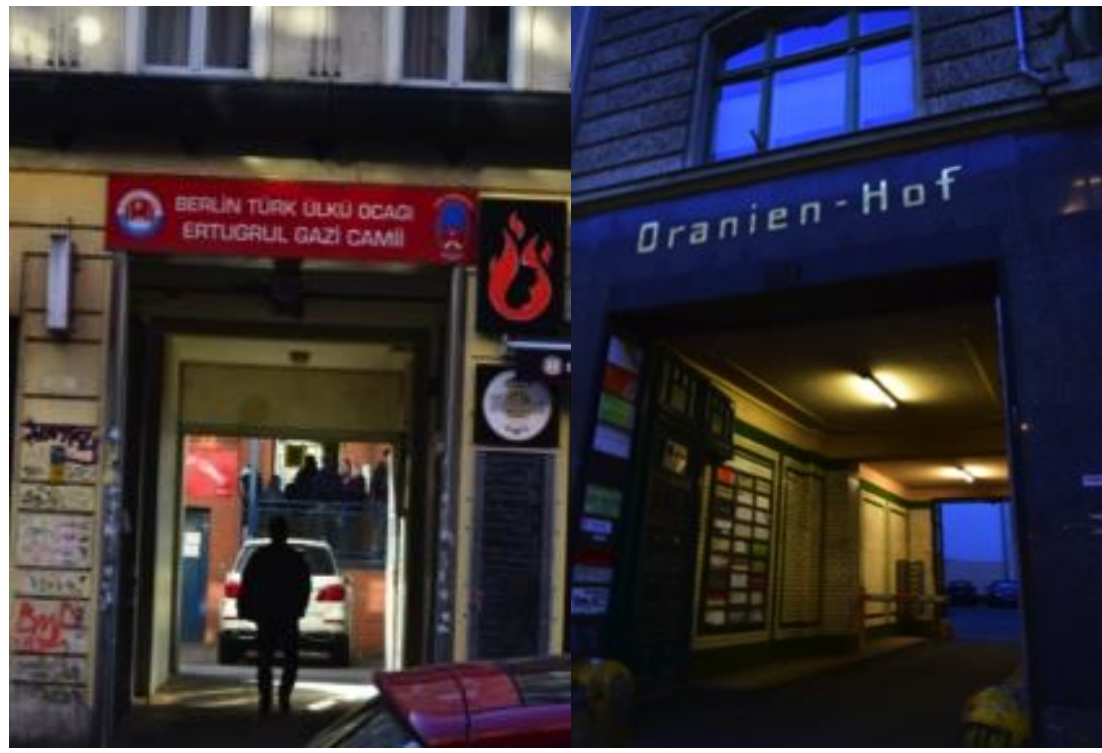

Figure 14. Views into Courtyards in Oranienstrasse

Source: Photographs by Megan Nottingham, 2014.

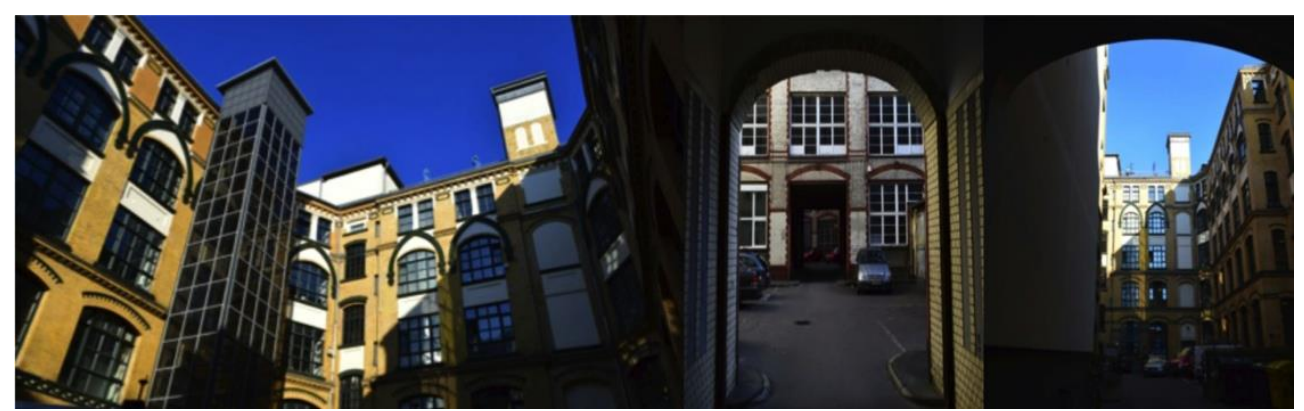

Figure 15. Views into Courtyards in Oranienstrasse

Source: Photographs by Megan Nottingham, 2014. 


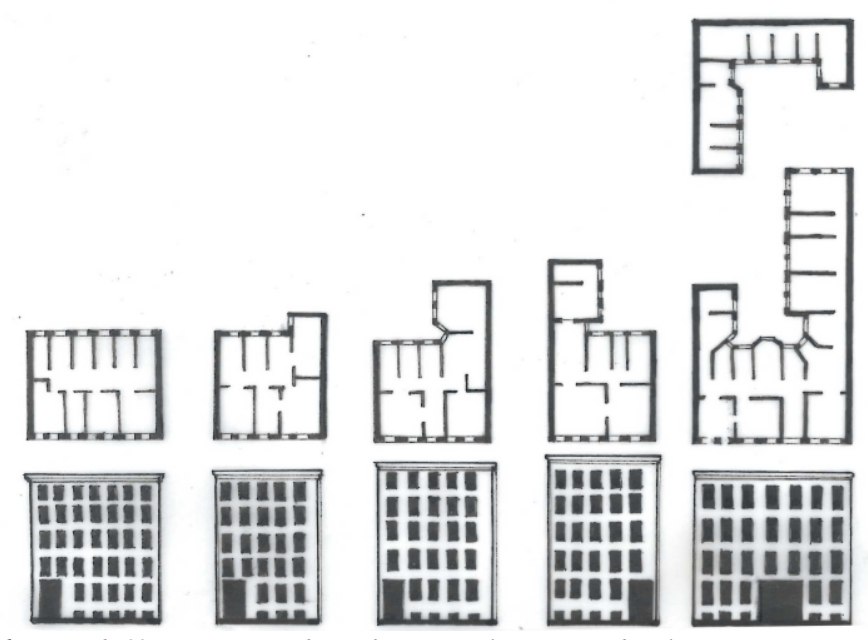

Figure 16. Undifferentiated Fabric; Plans and Elevations at Skalitzer Strasse Source: Redrawn by Megan Nottingham, 2014 from: S.T.E.R.N Archive, in Friedrichshain und Kreuzberg Museum, Berlin, 2014, Exhibition: Dauerausstellung'Geschichte wird gemacht! Berlin am Kotbusser Tor, Protestbewegung und Stadtsanierung in Kreuzberg SO36.

\section{Historical Continuities}

In many ways, Krier's Ritterstrasse has a number of spatial similarities to the nineteenth century structure. Its lining the street, clear definition of spaces and sequencing of courtyards are akin to its nineteenth century predecessor.

From an organisational perspective, Krier's archways allow a line of movement into the block that is similar to its nineteenth century predecessor. Figure 14 and Figure 15 show the voids of access and views into the courtyards. In Ritterstrasse, these lead to streets and courtyards, designed as landscaped spaces of relaxation. In that sense, they are 'programmed', and therefore do not perform like their nineteenth century predecessors, as generic voids amongst others that serve to contribute to circulation and draw in activity, social and economic, from the space of the street into the block and vice versa. In comparison to the nineteenth century block's courtyard, there is nothing flexible about Krier's. Here the ground surface clearly is assigned to the buildings surrounding it, and the functions inside are hardly open to adaptation - except from one size of dwelling to another.

Moreover, the significant qualities of the nineteenth century structure, which is also the reason for its continuous survival, is its accumulation of generous, undifferentiated spaces that allow changing patterns of uses over time. In its internal inhabitation, its spaces can be grouped and redistributed horizontally and vertically, its spaces arrayed, linked together or easily subdivided. In conjunction with this potentially changing pattern of internal organisation, the lack of differentiation of the courtyards allows an adaptable extension of this flexible inhabitation: it can form an extension to one or several businesses or workshops, it can allow access, it can incite through 
movement. It allows a flexible or natural distribution of programmes according to synergy effects, particularly through it relatively high permeability at ground level. It permits changing patterns of the distribution of programmes, and the potential for a changing distribution of programmatic intensities.

Of course today we cannot return to this fundamental lack of differentiation. It was partly the block itself that helped to establish the differentiation of the city into functionally and formally distinct quarters, and the emergence of the domestic space of the family as a defined set of spaces. ${ }^{26}$ While Krier's landscaped courtyard allows access into the block, and offers a space to the apartments surrounding it, both the apartment's spaces and the courtyard space are part of precisely defined sets of spaces, their lines in plan indicating clear demarcations rather than flexibly definable boundaries. The courtyard belongs to and is differentiated from the highly articulated, selfcontained apartments, instead of being a series of voids potentially spilling into each other as in the nineteenth century block. While access at ground level is granted, nevertheless it appears that the vertical line of the building elevation demarcates a sense of closure between the inside of the block and the space of the street. Here the block will not allow a changing pattern of use over time the internal differentiation between residences, and their respective courtyards, does not offer a different distribution of intensities across ground level or a change of uses horizontally and vertically.

As was argued previously, the space of the courtyard in the nineteenth century block was one amongst a series of voids spilling into each other with flexibly definable boundaries; the conception of a clear division between public and private spaces did not exist as such. The status of the ground surface in the courtyard was only to degrees different than the status of the street, and in turn, the series of generous undifferentiated rooms that constituted the block's interior were not seen as that distinct form the voids of the courtyard. The line of movement both of people and economic activities led from the street into and sometimes across the urban block, enabling a changing, flexible pattern of intensities particularly across ground level.

Furthermore, the block performed as one element of a spatial system that came to constitute the entire city. Its logic therefore was not and could not be singular, but relied on the repetition of the same logic across the urban fabric. Of course, we cannot revert back to the undifferentiated status of spaces that preceded the distinction of the public and the private that the block itself helped to generate. Krier's block, then, does not simply adapt nineteenth century spaces to twentieth conceptions of public and private, it forms spaces differently.

\section{Conclusions}

In the descriptions above, we seem to have encountered three different forms of understanding historical continuity. The first is exemplified in Krier's

26. Borsi, "Strategies of the Berlin Block". 
postmodern approach to using historical references. Quotations from the past, such as his references of Vienna's Karl-Marx-Hofe; the reconstruction of Schinkel's Feilner house with historic fragments taken from elsewhere, and other citations from across history can be seen as a form of visual imagery; snapshots that help to pluralize different readings. As we saw, these references to the past can be read positively as visual stimulation; claimed by Krier as identity forming as well as read as promoting the very loss of history in Hoffmann-Axthelm's reading; meaningless decorations or even regressive as read by Kleihues due to their lack of authenticity. We might or might not agree with Krier's approach to historical citation, but it appears that the very plurality of interpretations is based on a meaning assigned.

By contrast, we also have identified two versions of formal and spatial continuity between the nineteenth century block and Krier's Ritterstrasse. The first, as explained by Krier, is the reinstatement of the principle historical morphological qualities: the bounded streets and squares, and the sequence of a clear alternation between built volumes and defined voids. The series of well defined internal streets and courtyards in Ritterstrasse can be seen to take up some of the qualities of its nineteenth century predecessor: a variety of densely arranged living arrangements, grouped around communal spaces that can promote a range of individual and collective activities and association. However, aspects of his formal re-interpretation of the past led to rather static transpositions, for example in his use of the bourgeois drawing room as the central living space, which rendered his floorplans static as critiqued by Frampton and Berke.

We also argued that Krier's Ritterstrasse, despite its formal similarities, creates spaces quite differently to the nineteenth century block. Whereas Krier's sequence of open spaces clearly demarcates public, semi public and private activity, the original conception of the berlin block saw a fluidly defined boundary line across the space of the street all the way to the single room. Until today, this enables a range of programmes and activities, social and economic, to unfold from the block's interior to the space of the street and vice versa. In conjunction with the block's fundamentally undifferentiated and generous spaces, that can flexibly adapted and arrayed, we argue that it is this spatial performance which made the nineteenth century block such a successful example of persisting urbanism.

Seen in this light, the comparison between Ritterstrasse and the nineteenth century block served to identify different ways we can draw upon architecture's past. However, rather than focusing on the past as a repository of static forms and imagery, we sought to highlight that we might also draw upon the spatial and organizational specificity of previous architectural solutions to address urban problems of today. 


\section{Bibliography}

Assmann, Gustav. Grundrisse für städtische Wohngebäude. Mit Rücksicht auf die für Berlin geltende Bauordnung. [Dwelling Plans for Urban Apartments.] Berlin: 1862 .

Berke, Deborah. “Rob Krier Urban Projects 1968-1982.” In D., Berke, K., Frampton, S., Kolbowski and R., Krier, 10-13. New York: Institute for Architecture and Urban Studies: Rizzoli International Publications, 1982.

Bodenschatz, Harald. Berlin Urban Design, a Brief History. Berlin: DOM Publishers, 2010.

Bodenschatz, Harald, Vittorio Magnago Lampugnani and Wolfgang Sonne (Eds.) "25 Jahre Internationale Bauaustellung Berlin 1987. Ein Wendepunkt des europaischen Städtebaus." [25 Years Internationale Bauaustellung Berlin 1987. A Turning Point of European Urbansim.] In Bücher zur Stadtbaukunst Band 3. Sulgen: Deutsches Institut fur Stadtbaukunst: Niggli, 2012.

Borsi, Katharina. "Strategies of the Berlin Block." In Intimate Metropolis, 132-152. Edited by V. Di Palma, D. Periton and M. Lathouri. Abingdon, Oxon: Routledge, 2009.

Colquhoun, Alan. Modernity and the Classical Tradition, Architectural Essays 19801987. London: The MIT Press, 1989.

Frampton, Kenneth. "Rob Krier Urban Projects 1968-1982." In D. Berke, K. Frampton, S. Kolbowski and R. Krier, 2-9. New York: Institute for Architecture and Urban Studies: Rizzoli International Publications, 1982.

Frampton, Kenneth. Modern Architecture a Critical History. London: Thames and Hudson, 1987.

Housing Prototypes. Ritterstrrasse Nord, http: //housingprototypes.org/images/ ritterstr.01m [Accessed May 15, 2015].

Hoffmann, Peter. "Report from West Berlin."Architectural Record 173, no. 2 (1985): 67.

Hoffmann-Axthelm, Dieter. Wie kommt die Geschichte ins Entwerfen? Aufsätze zu Architektur und Stadt. [How does History enter Design? Articles on Architecture and the City.] Berlin: Springer Vieweg, 1987.

Geist, Jonas and Kürvers, Klaus. Das Berliner Mietshaus. [The Berlin Apartment House.] Munich: Prestel Verlag, 1980-89 (2): 279. (Landesarchiv Berlin F Rep. 270, Nr A 2999).

IBA Prospectus: IBA'87. Sudliche Friedrichstadt und Tegel, Baukultur und junge Stadtgeschichte im Focus [Southern Friedrichstadt and Tegel, Building Culture and Recent Urban History in Focus.] Berlin: Senatsverwaltung fur Stadtenwicklung und Umwelt, 2008.

Kleihues, Josef, Paul and Wolf Jobst Siedler (1977). "IBA's Models for a City: Housing and the Image of Cold-War Berlin." In Wallis Miller. The Journal of Architectural Education 46, no. 4 (1993): 205.

Kleihues, Josef and Heinrich Klotz (Ed.) "International Building Exhibition Berlin 1987." In Examples of New Architecture. London: Academy Editions, 1986.

Krätke, Stefan. The Interactive Knowledge Creation and the Urbanization Economies of Innovation. Malden MA: Willey-Blackwell, 2011.

Krier, Rob. Stadtraum in Theorie und Praxis. [Urban Space in Theory and Practice.] Stuttgart: Karl Kramer Verlag, 1975. Urban Space. New York: Rizzoli International, 1979. 
Vol. 2, No. $1 \quad$ Borsi: The Typology of the Berlin Block: History, Continuity...

. "Rob Krier Urban Projects 1968-1982." In D. Berke, K. Frampton, S. Kolbowski and R. Krier, 5. New York: Institute for Architecture and Urban Studies: Rizzoli International Publications, 1982a. . Architecture and Urban Design. London: Academy Editions, 1993.

Landesarchiv Berlin (LArch); B Rep. 150/416, Mitteilung Nr 105. Programm der 750jahr-Feier. [Programm of the 750 Year Celebration.] Internationale Bauaustellung: 10-11.

Pugh, Emily. The Berlin Wall and the Urban Space and Experience of East and West Berlin, 1961-1989. Michigan: 2008.

. "Beyond the Berlin Myth: The Local, the Global and the IBA 87." In Berlin Divided City, 1945-1989, 156-167. Edited by P. Broadbent and S. Hake. USA: 2010.

Ritterstrasse Nord: Friedrichstadt, Architectural Review, 9 (1987): 5.

Senatsverwaltung für Wirtschaft, Technologie, Forschhung. Räume der Kreativwirtschaft. [Spaces of the Creative Economy.] Berlin: 2008.

Senatsverwaltung für Stadtentwicklung und Umwelt. IBA, '87 - Sudliche Friedrichstadt und Tegel. Baukultur und junge Stadtgeschichte in Fokus. [IBA ' 87 - Southern Friedrichsstadt and Tegel. Building Culture and recent Urban History in Focus] Berlin: 2014.

S.T.E.R.N Archive. Dauerausstellung 'Geschichte wird gemacht! Berlin am Kotbusser Tor, Protestbewegung und Stadtsanierung in Kreuzberg SO36. [Permanent Exhibition: History is Being Made! Berlin Kotbusser Tor, Protest Movement and Urban Renewal in Kreuzberg SO36.] Berlin: Friedrichshain und Kreuzberg Museum, Exhibition, 2014.

Testa, Peter. "Unity of the Discontinuous: Alvaro Siza's Berlin Works." Assemblage, no. 2 (1987): 47. 